\title{
SINTESIS PAPAN KOMPOSIT BERBAHAN DASAR SERAT SABUT KELAPA DAN SERAT BUAH KETAPANG DENGAN MATRIK PVAC
}

\author{
Susilawati ${ }^{1)}$, Aris Doyan ${ }^{1)}$, Kosim $^{1}$, Napaani Syafaati²), Lalu Muliyadi²) \\ 1)Program Studi Pendidikan Fisika FKIP, Universitas Mataram, Mataram, NTB, Indonesia \\ ${ }^{2}$ Magister Pendidikan IPA, Program Pascasarjana Universitas Mataram, Mataram, NTB, Indonesia \\ Corresponding author: Susilawati \\ E-mail : susilawatihambali@unram.ac.id
}

Diterima 22 Agustus 2020, Disetujui 14 September 2020

\begin{abstract}
ABSTRAK
Sintesis komposit mengggunakan campuran serat sabut kelapa dan serat buah ketapang dengan matrik Polyvinil Acetat (PVAc) telah berhasil dilakukan. Sampel tersebut dibuat dengan variasi komposisi fraksi volume serat sabut kelapa dan serat buah ketapang yaitu (0:100), (30:70), (40:60), (50:50), (60:40), (70:30) dan (100:0)\%. Perbandingan fraksi volume campuran serat alami dan matrik polyvinyl Acetat (PVAc) yang dibuat yaitu (70:30)\%. Pembuatan sampel diawali dengan pengambilan serat sabut kelapa dan buah ketapang, penjemuran dan pemotongan, kemudian pencampuran serat sabut kelapa dan serat buah ketapang dengan matriks PVAc, pencetakan komposit dengan alat cetak tekan dan penjemuran. Sampel yang sudah jadi selanjutnya diuji fisiknya dengan cara menentukan nilai massa jenis dan kadar air sampel untuk melihat kualitas sampel. Hasil penelitian menunjukan bahwa secara keseluruhan sampel telihat homogen, massa jenis sampel berkisar antara 0,52- 0,72 gram $/ \mathrm{cm}^{3}$ dan nilai kadar air berkisar antara 10,05- 12,89\%. Hal ini berarti bahwa sampel komposit telah memenuhi kriteria SNI 03-02105-2006 dan termasuk pada katagori berkerapatan sedang.
\end{abstract}

Kata kunci: komposit; serat sabut kelapa; serat buah ketapang; PVAc.

\begin{abstract}
Synthesis using a mixture of Coconut coir fiber and Terminalia catappa fruit fiber with the Polyvinyl Acetate (PVAc) matrix has been successfully carried out. The samples were made with variations in the composition of the volume fraction of Coconut coir fiber and Terminalia catappa fruit fiber, namely (0: 100), (30:70), (40:60), (50:50), (60:40), (70:30) ) and (100: 0$) \%$. The ratio of the volume fraction of the mixture of natural fibers and the polyvinyl acetate (PVAc) matrix made was $(70: 30) \%$. The sample production begins with taking Coconut coir and Terminalia catappa fruit, drying and cutting, then mixing coconut coir and Terminalia catappa fruit fiber with a PVAc matrix, molding the composites using a press printing tool and drying. The finished sample is then physically tested by determining the density value and moisture content of the sample to see the quality of the sample. The results showed that the overall sample looked homogeneous, the density of the sample ranged from 0.52 to 0.72 grams $/ \mathrm{cm}^{3}$ and the moisture content ranged from 10.05 to $12.89 \%$. This means that the composite sample has met the SNI 03-02105-2006 criteria and is included in the medium density category.
\end{abstract}

Keywords: composite; coconut coir fiber; terminalia catappa fruit fiber; PVAc.

\section{PENDAHULUAN}

Indonesia merupakan Negara

kepulauan penghasil kelapa utama di dunia.

Kelapa merupakan tanaman perkebunan dengan areal terluas dibandingkan dengan tanaman karet dan kelapa sawit. Kelapa menempati areal seluas 3,70 juta ha dari 14,20 juta ha total areal perkebunan di Indonesia. Selain daging buahnya, bagian lain dari kelapa juga memiliki nilai ekonomis seperti tempurung, batang pohon dan daun kelapa, tetapi sabut kurang mendapat perhatian (Zulkifli, 2019).

Potensi limbah sabut kelapa yang begitu besar belum dimanfaatkan sepenuhnya untuk kegiatan produksi yang mempunyai nilai tambah ekonomis, dengan tidak adanya pemanfaatan yang optimal, limbah ini hanya akan menimbulkan masalah lingkungan. Masalah lingkungan yang mungkin timbul dari banyaknya sabut kelapa dapat dihindari dengan menjadikan sabut kelapa sebagai bahan dasar pembuatan komposit.

Sabut kelapa mengandung serat yang merupakan material serat alami sebagai alternatif dalam pembuatan komposit. Serat kelapa ini mulai dilirik penggunaannya karena selain mudah didapat, murah, dan dapat mengurangi polusi lingkungan 
(Biodegradability) (Wirawan, 2018). Pembuatan komposit dengan bahan dasar sabut kelapa sebelumnya telah dilakukan penelitian oleh Sarkar (2015), Hwang (2016), Pereira (2017), dan Oliveira (2018). Meskipun pembuatan komposit dari sabut kelapa cukup ekonomis, namun masih menghasilkan komposit yang terdapat retakan yang disebabkan kurang padatnya komposit (Ardanuy, 2015).

Salah satu upaya untuk menambahkan kekuatan komposit serat sabut buah kelapa adalah dengan menambahkan serat buah ketapang (Dahlan, 2018). Buah ketapang (Terminalia catappa) merupakan limbah potensial yang belum banyak dimanfaatkan. Serat alami buah ketapang memiliki potensi besar untuk dikembangkan. Buah ketapang terdistribusi secara luas di Indonesia (Durowaye, 2018). Tetapi pemanfaatan buah ketapang di Indonesia khususnya di kota Mataram belum optimal, pohon ini banyak tumbuh dan hanya dimanfaatkan sebagai pohon peneduh serta buahnya terbuang siasia menjadi limbah.

\section{METODE PENELITIAN}

Sintesis komposit pada penelitian ini mengggunakan serat alami yaitu campuran serat sabut kelapa (SSK) dan serat buah ketapang (SBK) dengan matrik Polyvinil Acetat (PVAc). Sampel tersebut dibuat dengan variasi komposisi fraksi volume SSK dan SBK yaitu $(0: 100) \%, \quad(30: 70) \%, \quad(40: 60) \%, \quad(50: 50) \%$, $(60: 40) \%, \quad(70: 30) \%$ dan $(100: 0) \%$. Perbandingan fraksi volume campuran serat alami dengan matrik polyvinyl Acetat (PVAc) yang dibuat yaitu (70:30)\%.

Pembuatan sampel diawali dengan pengambilan SSK dan SBK, penjemuran dan pemotongan serat, kemudian pencampuran SSK dan SBK dengan matriks PVAc, pencetakan komposit dengan alat cetak tekan dan penjemuran. Sampel yang sudah jadi selanjutnya diuji fisiknya dengan cara menentukan nilai massa jenis dan kadar air sampel untuk melihat kualitas sampel. Adapaun nilai massa jenis dan kadar air sampel dapat dicari dengan persaman 1 (Sudarsono, 2010) dan persamaan 2 (Kosim, 2017).

$$
\begin{aligned}
& \rho=\frac{f}{L \cdot W \cdot t} \\
& K A=\frac{m_{1}-m_{2}}{m_{2}} \times 100
\end{aligned}
$$

Dimana $\rho=$ massa jenis, $f=$ berat benda, $L=$ panjang benda, $W=$ lebar benda, $t=$ tebal benda, $\mathrm{KA}=$ kadar air, $\mathrm{m}_{1}=$ massa benda saat basah, $\mathrm{m}_{2}=$ massa benda saat kering.

\section{HASIL DAN PEMBAHASAN}

Pembuatan sampel papan komposit menggunakan persentase serat alam (SSK dan SBK) dan matriks PVAc sebesar $70 \%$ dan $30 \%$. SSK dan SBK dibuat dalam bentuk serbuk (Gambar 1). Sampel komposit dibuat dengan variasi komposisi SSK dan SBK yaitu $(0: 100) \%, \quad(30: 70) \%, \quad(40: 60) \%, \quad(50: 50) \%$, $(60: 40) \%,(70: 30) \%$, dan $(100: 0) \%$.

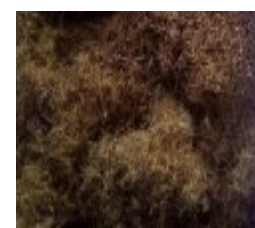

(a)

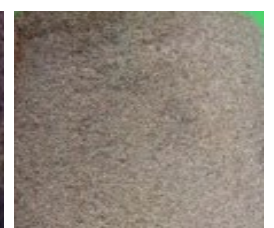

(b)
Gambar 1. (a) SSK dan (b) SBK.

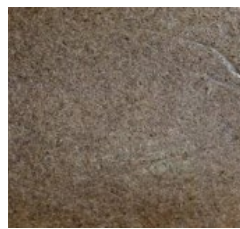

(a)

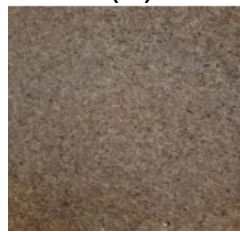

(d)

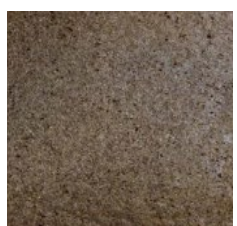

(b)

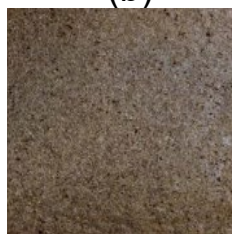

(e)

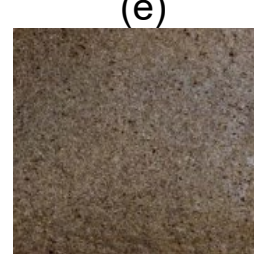

(g)

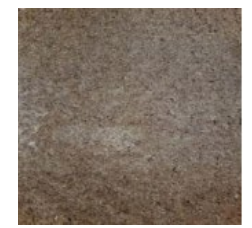

(c)

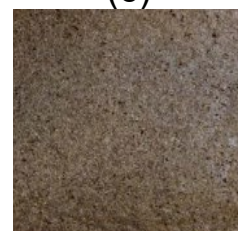

(f)
Gambar 2. Sampel Papan Komposit SSK dan SBK dengan Variasi Volume. (a) 0:100\%, (b) 30:70\%, (c) $40: 60 \%$, (d) $50: 50 \%$, (e) $60: 40 \%$, (f) $70: 30 \%$, dan (g) $100: 0 \%$.

Pembuatan sampel diawali dengan pengambilan SSK dan SBK, pemisahan serat dari cangkang, penjemuran dan pemotongan, kemudian pencampuran SSK dan SBK dengan matriks PVAc, pencetakan komposit dengan alat cetak tekan dan penjemuran. Sampel yang sudah jadi ditunjukan pada Gambar 2. Berdasarkan Gambar 2 terlihat jelas bahwa secara keseluruhan sampel telihat homogen. Hal ini berarti bahwa campuran SSK dan SBK terdistribusi sempurna dengan matriksnya (Taufik, 2020).

Sampel yang sudah jadi selanjutnya diuji fisiknya dengan cara menentukan massa 
jenis dan kadar air sampel untuk melihat kualitas sampel. Adapaun nilai massa jenis dan kadar air sampel dapat dicari dengan persaman 1 dan 2 .

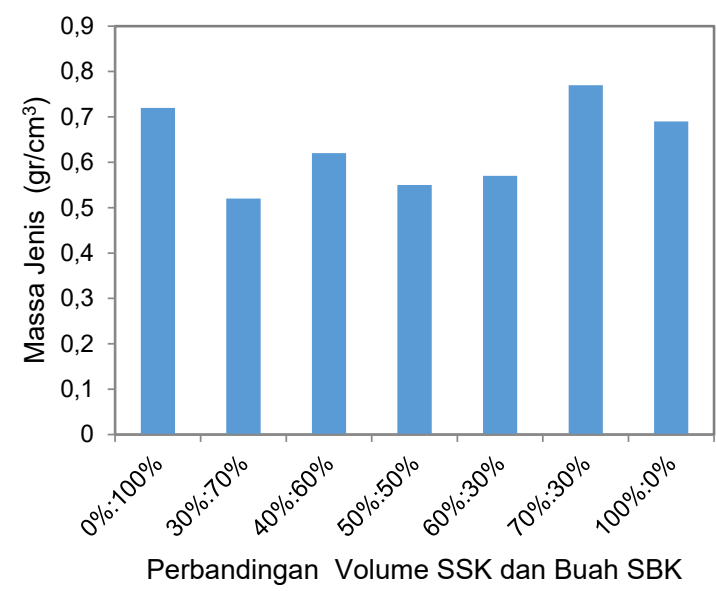

Gambar 3. Grafik Hubungan antara Fraksi Volume SSK dan SBK dengan Massa Jenis Sampel Komposit.

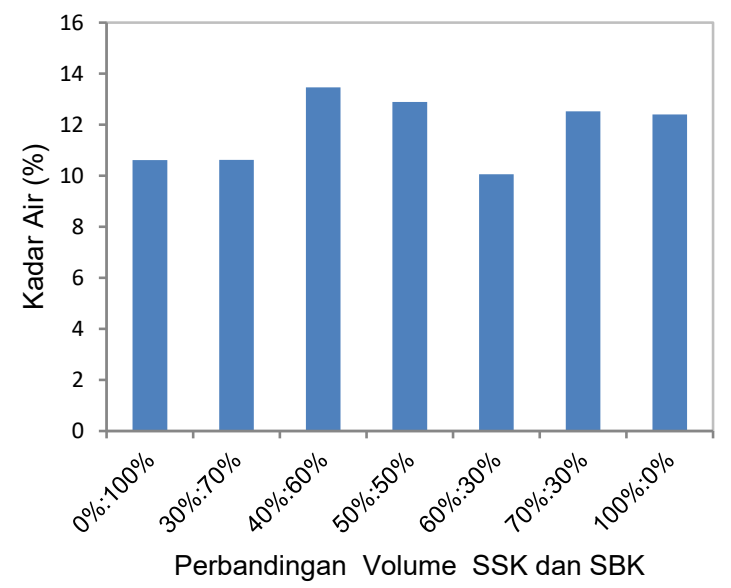

Gambar 4. Grafik Hubungan antara Fraksi Volume SSK dan SBK dengan Kadar Air Sampel Komposit.

Berdasarkan persamaan 1 dan 2 dapat diketahui bahwa nilai massa jenis sampel berkisar antara 0,52- 0,72 gram $/ \mathrm{cm}^{3}$ dan nilai kadar air berkisar antara 10,05- 12,89\%. Hal ini berarti bahwa sampel komposit memenuhi kriteria SNI 03-02105-2006 dan termasuk pada katagori berkerapatan sedang (Rahayu, 2015). Nilai standar SNI untuk massa jenis yaitu 0,5$0,9 \mathrm{gram} / \mathrm{cm}^{3}$, sedangkan untuk kadar air besarnya kurang dari $14 \%$ (Kosim, 2017). Nilai massa jenis dan kadar air dapat ditunjukan pada Gambar 3 dan 4.

\section{SIMPULAN DAN SARAN}

Sintesis komposit mengggunakan campuran SSK dan SBK dengan matrik Polyvinil Acetat (PVAc) telah berhasil dilakukan. Hasil penelitian menunjukan bahwa secara keseluruhan sampel telihat homogen, massa jenis sampel berkisar antara 0,52- 0,72 gram $/ \mathrm{cm}^{3}$ dan nilai kadar air berkisar antara 10,05-12,89\%. Hal ini berarti bahwa sampel komposit telah memenuhi kriteria SNI 0302105-2006 dan termasuk pada katagori berkerapatan sedang.

\section{UCAPAN TERIMAKASIH}

Ucapan terima kasih kami sampaikan kepada Laboraturium Fisika Unram serta semua pihak yang telah memberikan masukan dan tinjauan kritis guna penyempurnaan artikel ini.

\section{DAFTAR RUJUKAN}

Ardanuy, M., Claramunt, J., \& Toledo Filho, R. D. (2015). Cellulosic fiber reinforced cement-based composites: A review of recent research. In Construction and Building Materials. https://doi.org/10.1016/j.conbuildmat.2 015.01.035

Dahlan, I., Doyan, A., \& Kosim. (2018). Tensile Test of Terminalia Catappa Fruit Fiber Composite Material. IOSR Journal of Applied Physics (IOSRJAP). DOI: 10.9790/4861 1003026367

De Oliveira, W. L., Xavier, A. A. B., Chaves, R. C. F., De Souza, P. M., Silva, L. O., \& Fabri, É. S. (2018). ANALYSIS OF THERMAL ABSORPTION FROM COMPOSITE PRODUCED WITH GREEN COCONUT RESIDUE. Revista Brasileira de Energias Renováveis.

https://doi.org/10.5380/rber.v7i2.58245

Durowaye, S., Lawal, G., Sekunowo, O., \& Onwuegbuchulem, A. (2018). Synthesis and characterization of hybrid polypropylene matrix composites reinforced with carbonized Terminalia catappa shell particles and Turritela communis shell particles. Journal of Taibah University for Science.

https://doi.org/10.1080/16583655.2018 .1451112

Hwang, C. L., Tran, V. A., Hong, J. W., \& Hsieh, Y. C. (2016). Effects of short coconut fiber on the mechanical properties, plastic cracking behavior, and impact resistance of cementitious composites. Construction and Building Materials.

https://doi.org/10.1016/j.conbuildmat.2 


\subsection{9 .118}

Kosim, K., Wahyudi, W., Susilawati, S., \& Doyan, A. (2017). SIFAT MEKANIK PAPAN KOMPOSIT BERBAHAN DASAR SERAT SABUT KELAPA DAN SERAT BATANG PISANG. Jurnal Pendidikan Fisika Dan Teknologi. https://doi.org/10.29303/jpft.v3i2.413

Montoro, S., Pereira, G., Pereira, G., Lima, M., Jesus, B., Silva, E., Benini, K., \& Bandeira, C. (2017). Featuring High Impact Polystyrene Composites Strengthened with Green Coconut Fiber Developed for Automotive Industry Application. Journal of Research Updates in Polymer Science. https://doi.org/10.6000/19295995.2017.06.01.3

Sarkar, N., Sahoo, G., Khuntia, T., Priyadarsini, P., Mohanty, J. R., \& Swain, S. K. (2017). Fabrication of acrylic modified coconut fiber reinforced polypropylene biocomposites: Study of mechanical, thermal, and erosion properties. Polymer Composites. https://doi.org/10.1002/pc.23887

Sudarsono, Rusianto, T., \& Suryadi, Y. (2010). Pembuatan Papan Partikel Berbahan Baku Sabut Kelapa Dengan Bahan Pengikat Alami (Lem Kopal). Teknologi.

Taufik, M., Doyan, A., Susilawati, Hakim, S., \& Muliyadi, L. (2020). Acoustic characteristics board of areca nuts fiber composites. Journal of Physics: Conference Series. https://doi.org/10.1088/17426596/1572/1/012004

Wirawan, I. G. R. T., \& Surata, I. W. (2018). Pengaruh Fraksi Berat Terhadap Kekuatan Tarik Dan Lentur Komposit Polyester Serat Serabut Kelapa. Jurnal Teknik Desain Mekanika, 7 (2).

Zulkifli Ida Bagus, Z. D. (2019). Analisa Pengaruh Perlakuan Alkalisasi Dan Hydrogen Peroksida Terhadap Kekuatan Mekanik Komposit Serat Sabut Kelapa Bermatriks Epoxy. Jurnal POLIMESIN. 